\title{
USE OF ECONOMETRIC MODELS FOR ANALYSIS OF ENTERPRISE DEVELOPMENT ON THE EXAMPLE OF SEA TRADING PORTS
}

\author{
ВИКОРИСТАННЯ ЕКОНОМЕТРИЧНИХ МОДЕЛЕЙ \\ ДЛЯ АНАЛІЗУ РОЗВИТКУ ПІДПРИЕМСТВА \\ НА ПРИКЛАДІ МОРСЬКИХ ТОРГОВЕЛЬНИХ ПОРТІВ
}

\author{
Olga B. Girina \\ olga.girina63@gmail.com \\ ORCID: 0000-0001-5917-6551 \\ Alina S. Lytvynenko \\ alina.litvinenko2208@gmail.com \\ ORCID: 0000-0002-9987-2540
}

\author{
О. Б. Гіріна, \\ канд. екон. наук, доцент \\ А. С. Литвиненко, \\ студентка
}

\author{
Odessa National Maritime University, Odessa \\ Одеський національний морський університет, м. Одеса
}

\begin{abstract}
The article considers econometric models for the purposes of analysis and forecasting of enterprise development. The characteristics of two-factor production functions are given: functions with fixed proportions of factors (Leontief function), multiplicative production function (Cobb-Douglas function), linear function, Allen function, functions of constant elasticity of substitution of factors (CES functions). They allow to connect the size of production results with the costs of enterprise resources: production assets and the number of production workers. The situations in economics for their use are given.

For the analysis and forecast of development of sea trade ports two directions of use of econometric models are defined: first, studying of dynamics of cargo flows of sea ports; second, the assessment of the impact of resources on gross income. An overview of scientific research in these areas is given.

The research method is statistical modeling of the Cobb-Douglas function, calculation of its parameters using the least squares method using Excel Solution Search. The object of research is the ports of Ukraine. The subject of the study is the impact of production resources on the development of these enterprises.

Based on statistics the Cobb-Douglas function in the growth rate was constructed, the total shares of fixed assets, the number of employees in the income growth rate were calculated, the influence of intensive and extensive production on the income growth rate was analyzed. The shares of extensive and intensive income growth at the expense of funds and numbers were studied.

Equilibrium development is characterized by equal growth rates of gross income and the volume of fixed assets. Using the equilibrium rate of capital investment, the company achieves the most sustainable development. The indicators of the actual, equilibrium rate of capital investment and their efficiency were analyzed. These figures are related to the coefficients of elasticity of the Cobb-Douglas function and the growth rate of enterprise resources.

Application of Cobb-Douglas function allowed to identify the strengths and weaknesses of enterprises, to determine the conditions for balanced development and increase production efficiency. Calculations make it possible to forecast and analyze gross income or production volumes depending on the factors of production of extensive and intensive nature.

Key words: econometric models; Cobb-Douglas function; extensive; intensive factor of production; equilibrium development; sea trade ports.
\end{abstract}

\footnotetext{
Анотація. У статті розглядаються економетричні моделі для цілей аналізу та прогнозу розвитку підприємства. Охарактеризовано двофакторні виробничі функції, які дозволяють пов'язати розмір результатів виробничої діяльності з витратами ресурсів підприємства: функції з фіксованими пропорціями чинників (функція Леонтьєва), мультиплікативної виробничої функції (функції Кобба-Дугласа), лінійної функції, функції Аллена, функції постійної еластичності заміщення чинників (функції CES). Наведені приклади ситуацій в економіці для їх використання.

Для аналізу та прогнозу розвитку морських торговельних портів визначено два напрями використання економетричних моделей, як-от вивчення динаміки вантажопотоків морських портів і оцінка впливу обсягів ресурсів на валовий дохід. Подано огляд наукових досліджень у цих напрямах.
} 
Методом дослідження є статистичне моделювання функції Кобба-Дугласа, розрахунок ії параметрів із використанням методу найменших квадратів за допомогою програми Excel «Пошук рішення». Об'єктом дослідження $€$ порти України. Предметом - вплив виробничих ресурсів на розвиток цих підприємств.

На основі статистичних даних побудована функція Кобба-Дугласа в темпах приросту, розраховані загальні частки основних виробничих фондів, чисельності працівників у темпах приросту доходу, аналізується вплив інтенсивного та екстенсивного виробництва на темп приросту доходу. Вивчаються частки екстенсивного та інтенсивного приросту доходу за рахунок фондів та чисельності.

Рівноважний розвиток характеризується рівністю темпів приросту валового доходу та обсягу основних виробничих фондів. Використовуючи рівноважну норму капітальних вкладень, підприємство досягає найбільш сталого розвитку. Для аналізу характеру розвитку розглянуто показники фактичної рівноважної норми капітальних вкладень та їх ефективності. Ці показники пов’язані з коефіцієнтами еластичності функції Кобба-Дугласа та темпами приросту ресурсів підприємства.

Застосування функції Кобба-Дугласа дозволило виявити сильні та слабкі сторони підприємств, визначити умови збалансованого розвитку та підвищення ефективності виробництва. Розрахунки дають змогу прогнозувати та аналізувати валовий дохід або обсяги виробництва залежно від факторів виробництва екстенсивного та інтенсивного характеру.

Ключові слова: економетричні моделі; функція Кобба-Дугласа; екстенсивні; інтенсивний фактори виробництва; рівноважний розвиток; морські торговельні порти.

\section{ПОСТАНОВКА ЗАВДАННЯ}

Управління розвитком підприємств морського транспорту в ринкових умовах потребує використання методів, які дозволяють узгоджувати роботу підприємств у складних економічних обставинах. Економіко-математичне моделювання дає такі можливості завдяки гармонічному поєднанню статистичних методів, методів оптимізації рішень, економічної кібернетики. Під час аналізу економічних явищ на основі економіко-математичних методів особливо важливими є економетричні моделі, що виявляють кількісні зв'язки між досліджуваними показниками і чинниками, які на них впливають. Ці моделі виступають як засіб аналізу і прогнозування економічних процесів на основі реальної статистичної інформації.

Економетричні моделі містять достатньо широкий клас різноманітних економіко-математичних моделей. Серед них виробнича функція відображає залежність результату від витрат ресурсів [1]. Як ресурси (чинники виробництва) на макрорівні здебільшого розглядаються накопичена (уречевлена) праця у формі виробничих фондів (капітал) $K$ і поточна (жива) праця $L$. А як результат - валовий випуск продукції $X$ (валовий дохід).

Розглянемо двофакторні виробничі функції (далі-ВФ).

1. Функція з фіксованими пропорціями чинників (функція Леонтьєва).

$$
y=\min \left(\frac{x_{1}}{a_{1}}, \frac{x_{2}}{a_{2}}\right),
$$

де $x 1, x 2$ - факторні признаки; $a_{1}, a_{2}$ - параметри.

Функція Леонтьєва призначена для моделювання суворо детермінованих технологій, які не допускають відхилення від технологічних норм і нормативів щодо використання ресурсів на одиницю продукції.
Як правило, вона використовується для формалізованого опису дрібномасштабних або цілком автоматизованих об'єктів.

2. Мультиплікативна ВФ задається виразом (2):

$$
X=A K^{a 1} \cdot L^{a 2}, a_{1}>0, a_{2}>0,
$$

де $A$ - коефіцієнт нейтрального технічного прогресу; $a_{1}, a_{2}$ - коефіцієнти еластичності за фондами $K$ i працею $L$ відповідно, за відсутності одного з ресурсів виробництво неможливе. Частковим випадком неокласичної мультиплікативної ВФ є функція КоббаДугласа: $X=A \cdot K^{\alpha} \cdot L^{1-\alpha}, \quad \alpha_{1}=\alpha, \alpha_{2}=1-\alpha$.

Параметри функції: $A, \alpha_{1}, \alpha_{2}$ можуть бути визначені з використанням методу найменших квадратів за допомогою низки стандартних пакетів прикладних програм, які реалізують метод множинної регресії.

Параметр $A$ інтерпретують як параметр нейтрального технічного прогресу: за тих самих значень $\alpha_{1}$ i $\alpha_{2}$ випуск у точці $(K, L)$ буде тим більшим, чим більше $A$.

Якщо $\alpha_{1}+\alpha_{2}>1$, то випуск зростає швидше, ніж у середньому зростають чинники, тобто має характер інтенсивного виробництва, а якщо $\alpha_{1}+\alpha_{2}<1$ - повільніше. Якщо $\alpha_{1}+\alpha_{2}=1$, то говорять про екстенсивний ріст, що зумовлюється лише кількісним ростом виробничих факторів.

Отже, якщо $\alpha_{1}+\alpha_{2}>1$, то ВФ описує зростальну економіку.

Функція Кобба-Дугласа найчастіше використовується для формалізованого опису середньомасштабних господарських об'єктів та економіки країни.

3. Лінійна функція розраховується за формулою (3).

$$
y=a_{1} x_{1}+a_{2} x_{2} .
$$

Лінійна функція застосовується для моделювання великомасштабних систем (велика галузь, народне господарство загалом), у яких випуск продукції $€$ результатом одночасного функціонування великої 
кількості різноманітних технологій. Особливу роль відіграє гіпотеза постійності граничних виробничих чинників чи їх необмеженого заміщення.

4. Функція Аллена

$$
y=a_{0} x_{1} x_{2}-a_{1} x_{1}^{2}-a_{2} x_{2}^{2}
$$

визначається за такими умовами: швидкості зростання граничних продуктивностей є постійними, функція є однорідною.

Функція Аллена за $a_{1}>0, a_{2}>0$ призначається для формалізованого опису виробничих процесів, у яких надмірне зростання будь-якого з чинників негативно впливає на обсяг випуску продукції. Така функція використовується для формалізованого опису дрібномасштабних виробничих систем з обмеженими можливостями переробки ресурсів.

5. Функція постійної еластичності заміщення чинників (функція CES):

$$
y=\left(a_{1} x_{1}^{a_{3}}+a_{2} x_{2}^{a_{3}}\right)^{a_{4}} .
$$

Функція CES застосовується у разі відсутності точної інформації щодо рівня взаємозаміни виробничих чинників. $€$ підстави вважати, що цей рівень суттєво не зміниться за умов зміни обсягів залучених ресурсів, тобто коли економічна технологія має властивість певної стійкості щодо певних пропорцій чинників. Функція CES (за наявності засобів оцінки іiі параметрів) може використовуватись для моделювання систем будь-якого рівня [1].

Таким чином, існує широкий вибір моделей, які можна використовувати для прогнозування розвитку підприємств морських торгових портів.

\section{АНАЛІЗ ОСТАННІХ ДОСЛІДЖЕНЬ І ПУБЛІКАЦІЙ}

Моделювання розвитку морських торговельних портів має починатися з прогнозування вантажопотоків для переробки, що формує обсяг попиту на послуги портів. Прогнозна динаміка вантажів, які мають бути перевантажені в морських портах, повинні враховуватися в процесі розробки нових інвестиційних проєктів. Дослідження в цьому напрямі проводилися, наприклад, у роботах [2-4].

У роботі [2] на підставі статистичних даних формується прогноз вантажопотоків через морські порти України за системою моделей рівнянь регресії, у яких факторною ознакою є обсяг регіональної морської торгівлі країн із перехідною економікою.

У роботі [3] досліджено експортні вантажопотоки Росії через морські порти та виявлено взаємозв'язки між ними та економікою загалом за період із 2006 р. до 2016 р. Отримано оцінки залежності обсягів вантажообігу від таких показників, як індекс промислового виробництва та валовий внутрішній продукт у поточних цінах.

Удосконалений алгоритм побудови прогнозної економетричної моделі в дослідженні [4] містить розрахунок перспективних величин факторів ризику та невизначеності, значення яких використовуються для прогнозування вантажообігу морського порту. Нетрадиційний підхід до короткострокового прогнозування обсягу вантажообігу морського порту з використанням штучних нейронних мереж підвищує надійність моделей прогнозу, оскільки вони легко адаптуються до змін факторів ризику.

У дисертації [5] обгрунтовано методи планування обробки вантажів у морських портах, заснованих на застосуванні імітаційного моделювання, що дозволяє виявляти резерви зростання ефективності обробки вантажів за умов великої кількості керованих змінних.

У роботі [6] для визначення оптимального поєднання параметрів у процесі стратегічного планування розвитку портової інфраструктури запропоновано застосовувати сценарний підхід у поєднанні з методом імітаційного моделювання. 3 використанням розробленої імітаційної моделі системи «морський порт - «сухий» порт», створеної в програмному середовищі AnyLogic, проведено експерименти 3 модельними даними. Результати експериментів дозволили підтвердити обгрунтованість вибору основних параметрів «сухих» портів, а також взаємозалежності між цими параметрами.

Іншим напрямом дослідження $є$ оцінка впливу ресурсів портів на обсяги виробничої діяльності, які характеризують пропозицію послуг. Автор [7]

використовує математичну модель для прогнозної оцінки ресурсів Одеського порту, яка може бути вдосконалена для інших портів.

У роботах [8; 9] для цілі оцінки впливу обсягів ресурсів на валовий дохід та обсяги перевантажувальних робіт використовується функція Кобба-Дугласа. У статті [9] робиться висновок, що в ринкових умовах для максимізації свого прибутку порт повинен прагнути до рівноваги між своїми потужностями та попитом на його послуги. Як недолік, так і надлишок виробничих потужностей спричиняють собою втрату потенційного прибутку.

Використання функції Кобба-Дугласа не отримало в попередніх роботах вичерпних досліджень, тому вона потребує додаткового вивчення на прикладі реальних об'єктів.

Метою дослідження $\epsilon$ використання економетричної моделі для цілей аналізу розвитку морських торговельних портів України та виконання за цією моделлю розрахунків впливу на ефективність розвитку основних факторів виробництва. Методом дослідження $є$ статистичне моделювання функції КоббаДугласа, розрахунок іiі параметрів із використанням методу найменших квадратів за допомогою програми Excel «Пошук рішення». Об’єктом дослідження є порти України. Предметом - вплив виробничих ресурсів на розвиток цих підприємств. 


\section{ОСНОВНИЙ МАТЕРІАЛ ДОСЛІДЖЕННЯ}

Для моделювання та аналізу розвитку підприємств морського транспорту найчастіше використовується функція Кобба-Дугласа. Для системи морських торговельних портів України 19902000 pp. розрахована функція Кобба-Дугласа за допомогою Excel «Пошук рішень» із параметрами $A=0.013, a 1=0.665 ; a 2=0.581$ :

$$
X_{t}=0.013 * K_{t}^{0.665 * L_{t}^{0.581}}
$$

Сума коефіиіснтів еластичності функиії (6) дорівнює $n=a 1+a 2=1,246>1$, що дозволяє говорити про інтенсивний характер розвитку портів у цей період. Динамічна функція Кобба-Дугласа може бути представлена в темпах приросту. Темп приросту доходу $x T(t)$ визначається за формулою (7):

$$
\begin{aligned}
& x(t)=\frac{\partial X}{\partial t} * \frac{1}{X_{t}}=\frac{\partial X}{\partial K} * \frac{\partial K}{\partial t} * \frac{1}{X_{t}}+\frac{\partial X}{\partial L} * \frac{\partial L}{\partial t} * \frac{1}{X_{t}}= \\
= & \frac{a 1 * A * K_{t}^{a 1} * L_{t}^{a 2} * \frac{\partial K}{\partial t}}{K_{t} * X_{t}}+\frac{a 2 * A * K_{t}^{a 1} * L_{t}^{a 2} * \frac{\partial L}{\partial t}}{L_{t} * X_{t}}=,(7) \\
= & a 1 * k(t)+a 2 * l(t)=x(t)
\end{aligned}
$$

де $k(t)$ - темп приросту основних виробничих фондів (далі - ОВФ);

$l(t)$ - темп приросту чисельності працівників;

$a 1, a 2$ - коефіцієнти еластичності функції КоббаДугласа

У сумі $a 1+a 2=n$ доля екстенсивних факторів зростання дорівнює 1. Частка факторів інтенсивного зростання (n-1).

Проаналізуємо розвиток системи морських портів України за 1991-2000 рр. на підставі функції Кобба-Дугласа (6) у такій послідовності [10].

1. Теоретичне значення середньорічного приросту доходів $x T(t)$ розрахуємо за формулою (7).
Виходячи $з$ виразу (7), частка ОВФ у темпі приросту доходів визначається за формулою (8):

$$
x K(t)=\frac{a 1 \cdot k(t)}{x T(t)} * 100 \% .
$$

2. Частка чисельності (L) в темпах приросту доходів визначається за формулою (9):

$$
x L(t)=\frac{a 2 \cdot l(t)}{x T(t)} * 100 \% .
$$

За даними таблиці 2, можна зробити висновки про найбільший вплив приросту основних виробничих фондів на приріст доходів портів, який відбувався у середині (1996-1997 рр.) та наприкінці (у 2000 р.) розглянутого періоду. У ці ж роки вплив приросту чисельності робітників був негативним.

Розглянемо коефіцієнти еластичності екстенсивного виробництва $m$; $(1-m)$ відповідно для основних виробничих фондів К та чисельності працівників L $(10 ; 11)$ та їх зв'язок із коефіцієнтами $a 1, a 2$ функції $(2 ; 6)$ :

$$
\begin{gathered}
m=\frac{a 1}{n}, a 1=m^{*} n ; \\
a 2=n-a 1=n-n^{*} m=n(1-m)
\end{gathered}
$$

У розрахунках на прикладі портів $m=0.665 / 1.246=0.534 ; . m-1=0.466$.

Щоб виокремити інтенсивний складник функції Кобба-Дугласа замінюємо вираз (2) формулою (12):

$$
X_{t}=A_{0} * K_{t}^{m} * L_{t}^{1-m} *\left(K_{t}^{m} * L_{t}^{1-m}\right)^{n-1}=A_{0} * K_{t}^{m} * L_{t}^{1-m} * H_{t} ;
$$

де $H(t)$ - коефіцієнт впливу інтенсивного виробництва.

3. Коефіцієнт інтенсивного виробництва

\begin{tabular}{|c|c|c|c|c|c|}
\hline Роки & Дохід, млн грн & ОВФ, млн грн & $\begin{array}{c}\text { Чисельність } \\
\text { робітників, ос. }\end{array}$ & $\begin{array}{c}\text { Апроксимація } \\
X=A K^{a 1} \cdot L^{a 2}\end{array}$ & $\begin{array}{c}\text { Функція найменших } \\
\text { квадратів }\end{array}$ \\
\hline $\mathrm{t}$ & $\mathrm{X}$ порт & К порт & L порт & aprX & Zmin \\
\hline 1991 & 247,561 & 432,0 & 22314 & 252,597 & 25,360 \\
\hline 1992 & 262,214 & 479,9 & 22317 & 270,919 & 75,777 \\
\hline 1993 & 280,125 & 520,2 & 22752 & 289,070 & 80,012 \\
\hline 1994 & 312,511 & 566,4 & 23951 & 315,164 & 7,043 \\
\hline 1995 & 344,432 & 598,7 & 24705 & 332,948 & 131,876 \\
\hline 1996 & 358,322 & 645,9 & 24601 & 349,330 & 80,860 \\
\hline 1997 & 376,343 & 689,1 & 24417 & 363,116 & 174,947 \\
\hline 1998 & 393,193 & 770,0 & 24445 & 391,204 & 3,958 \\
\hline 1999 & 415,917 & 870,5 & 24751 & 427,545 & 135,214 \\
\hline 2000 & 442,347 & 920,3 & 24653 & 442,642 & 0,087 \\
\hline Сума & 3432,965 & 6493,0 & 238906 & 3434,535 & 715,135 \\
\hline$m=a 1 / n$ & 0,534 & $A$ & 0,013 & $a 1$ & 0,665 \\
\hline $1-m$ & 0,466 & $a 2$ & 0,581 & $n=a 1+a 2$ & 1,246 \\
\hline
\end{tabular}

$$
H_{t}=\left(K_{t}^{m} * L_{t}^{m-1}\right)^{n-1}
$$

4. Темп приросту доходу за рахунок інтенсивного виробництва можна розрахувати так:

$$
h(t)=\frac{d H_{t}}{d t} * \frac{1}{H_{t}}=m(n-1) * k(t)+(1-m)(n-1) * l(t)
$$

Таблиця 1. Розрахунок параметрів функції Кобба-Дугласа для аналізу розвитку морських торговельних портів за 1991-2000 pp. 


\section{ЕКОНОМІКА ТА МЕНЕДЖМЕНТ № 4-2021}

$h(t)$ - темп науково-технічного прогресу (далі - НТП), що акумулює вдосконалення техніки, покращення організації виробництва.

Теоретичний темп приросту доходу розраховується за формулою(15):

$$
x T(t)=m^{*} k(t)+(1-m) * l(t)+h(t)
$$

Формули (7), (15) дозволяють досліджувати частки впливу на темп приросту доходів факторів виробництва - виробничих фондів та чисельності.

5. Частка екстенсивного приросту доходів за рахунок ОВФ (16):

$$
x_{e K}(t)=\frac{m^{*} k(t)}{x T(t)} * 100,
$$

6. Частка екстенсивного приросту доходів за рахунок чисельності (17):

$$
x_{e L}(t)=\frac{(1-m) * l(t)}{x T(t)} * 100,
$$

7. Частка інтенсивного приросту доходу (18):

$$
x i(t)=\frac{h(t)}{x T(t)} * 100 .
$$

8. Частка інтенсивного приросту доходу за рахунок росту кваліфікації працівників:

$$
X i l(t)=\frac{(a 2-(1-m)) * l(t)}{x T(t)} .
$$

9. Частка інтенсивного приросту доходу за рахунок вдосконалення ОВФ:

$$
X i k(t)=\frac{(a 1-m) * k(t)}{x T(t)} \cdot * 100 \%
$$

10. Фактична норма капітальних вкладень:

$$
A f(t)=\frac{d K(t)}{X(t)}=\frac{K(t)-K(t-1)}{X(t)} .
$$

11. Ефективність капітальних вкладень:

$$
e(t)=\frac{d X(t)}{d K(t)}=\frac{X(t)-X(t-1)}{K(t)-K(t-1)} .
$$

12. Норма капітальних вкладень рівноважного розвитку:

$$
\operatorname{Ar}(t)=\frac{1}{e(t)} *\left(l(t)+\frac{h(t)}{1-m}\right) .
$$

\begin{tabular}{|c|c|c|c|c|}
\hline Роки & $\begin{array}{c}\text { Tеоретичний приріст } \\
\text { доходів } \\
\end{array}$ & $\begin{array}{l}\text { Частка ОВФ в темпі } \\
\text { приросту доходів (\%) }\end{array}$ & $\begin{array}{c}\text { Частка чисельності в темпах } \\
\text { приросту доходів (\%) } \\
\end{array}$ & Перевірка \\
\hline $\mathbf{t}$ & $x T(t)(7)$ & $x K(t)(8)$ & $x L(t)(9)$ & \\
\hline 1 & 2 & 3 & 4 & $5=3+4$ \\
\hline 1991 & - & - & - & - \\
\hline 1992 & 0,066 & 99,883 & 0,117 & 100,00 \\
\hline 1993 & 0,063 & 82,274 & 17,726 & 100,00 \\
\hline 1994 & 0,083 & 65,113 & 34,887 & 100,00 \\
\hline 1995 & 0,054 & 66,941 & 33,059 & 100,00 \\
\hline 1996 & 0,046 & 105,319 & $-5,319$ & 100,00 \\
\hline 1997 & 0,037 & 111,724 & $-11,724$ & 100,00 \\
\hline 1998 & 0,071 & 99,057 & 0,943 & 100,00 \\
\hline 1999 & 0,084 & 91,451 & 8,549 & 100,00 \\
\hline 2000 & 0,034 & 106,853 & $-6,853$ & 100,00 \\
\hline
\end{tabular}

Рівноважний розвиток характеризується рівністю темпів приросту валового доходу та обсягів основних виробничих фондів. Використовуючи рівноважну норму капітальних вкладень, підприємство досягає найбільш сталого розвитку.

Таблиця 2. Розрахунок часток приросту доходів за факторами виробництва

Джерело: розраховано авторами

Таблиця 3. Розрахунок темпів приросту доходів та факторів виробництва морських торговельних портів за 1991-2000 рр.

\begin{tabular}{|c|c|c|c|c|c|}
\hline Роки & $\begin{array}{c}\text { Фактичний } \\
\text { темп приросту } \\
\text { доходів }\end{array}$ & $\begin{array}{c}\text { Фактичні } \\
\text { темпи приросту } \\
\text { ОВФ }\end{array}$ & $\begin{array}{c}\text { Фактичні } \\
\text { темпи приросту } \\
\text { чисельності }\end{array}$ & $\begin{array}{c}\text { Коефіціснт інтенсивного } \\
\text { виробництва(13) }\end{array}$ & $\begin{array}{c}\text { Темп приросту } \\
\text { інтенсивного } \\
\text { виробництва (14) }\end{array}$ \\
\hline $\mathbf{t}$ & $\mathbf{x ( t ) ф а к т ~}$ & $\mathbf{k}(\mathbf{t})$ & $\mathbf{l}(\mathbf{t})$ & $\mathbf{H t}$ & $\mathbf{\text { h(t) }}$ \\
\hline 1991 & - & - & - & 7,0877 & 0,0137 \\
\hline 1992 & 0,0559 & 0,0998 & 0,0001 & 7,1790 & 0,0127 \\
\hline 1993 & 0,0639 & 0,0775 & 0,0191 & 7,3026 & 0,0169 \\
\hline 1994 & 0,1036 & 0,0816 & 0,0501 & 7,3821 & 0,0094 \\
\hline 1995 & 0,0927 & 0,0540 & 0,0305 & 7,4524 & 0,0076 \\
\hline 1996 & 0,0388 & 0,0731 & $-0,0042$ & 7,5096 & 0,0146 \\
\hline 1997 & 0,0479 & 0,0627 & $-0,0075$ & 7,6208 & 0,0174 \\
\hline 1998 & 0,0429 & 0,1051 & 0,0011 & 7,7556 & 0,0068 \\
\hline 1999 & 0,0546 & 0,1155 & 0,0124 & & \\
\hline 2000 & 0,0598 & 0,0541 & $-0,0040$ & & \\
\hline
\end{tabular}

Джерело: розраховано авторами 
13. Середні величини норми капітальних вкладень знаходять як середні геометричні для фактичних $(\operatorname{Af}(\mathrm{t}))$ та рівноважних $(\operatorname{Ar}(\mathrm{t}))$ значень.

\section{ОБГОВОРЕННЯ ОТРИМАНИХ РЕЗУЛЬТАТІВ}

У розрахунках за 1991-2000 pр. середня фактична норма капітальних вкладень удвічі більша, ніж середня норма капітальних вкладень рівноважного розвитку за рахунок відставання темпу приросту доходів від темпу приросту виробничих фондів.

Середня ефективність капітальних вкладень за період становить 0,404 .

На прикладі морських портів визначена (табл. 4) частка впливу на темп приросту доходу інтенсивних факторів виробництва дорівнює 19\%

$$
\left(\frac{1-n}{n} * 100=0.246 / 1.246 * 100=19,7 \%=x i(t)\right) .
$$

Вплив екстенсивних факторів зростання за рахунок фондів у темпі приросту доходу за розглянутий період коливався від 52,26 до 89,67\%. Вплив екстенсивних факторів зміни чисельності працівників в темпі приросту доходу невеликий та коливався від
$-9,41 \%$ до 28,00\%. Таким чином, приріст доходів портів відбувався за рахунок екстенсивного зростання основних виробничих фондів.

Приблизна рівність між нормою капітальних вкладень фактичною $(0,24)$ та рівноважною $(0,21)$ відбувалося у 1999 р. (табл. 5), що привело до зближення темпів зростання доходів $(0,598)$ та виробничих фондів $(0,541)$ у 2000 р. (табл. 2). Такі зміни в темпах зростання стали причиною росту ефективності капітальних вкладень у 2000 р. $(0,53)$.

\section{ВИСНОВКИ}

У дослідженні доведено, що аналіз розвитку підприємства на підставі функції Кобба-Дугласа дозволяє побачити його сильні та слабкі сторони та головні фактори екстенсивного та інтенсивного характеру, які впливають на зростання доходів портів та ефективність їх розвитку. Використання статистичного моделювання має поєднувати аналіз внутрішніх та зовнішніх факторів виробництва для аналізу попиту та пропозиції послуг підприємства на ринку, що буде напрямом подальших досліджень.

Таблиця 4. Розрахунок часток приросту доходів морських торговельних портів за рахунок екстенсивних та інтенсивних факторів виробництва

\begin{tabular}{|c|c|c|c|c|c|}
\hline \multirow{2}{*}{ Роки } & $\begin{array}{c}\text { Теоретичний } \\
\text { приріст доходів }\end{array}$ & $\begin{array}{c}\text { Частка екстенсивного } \\
\text { приросту доходів 3а } \\
\text { рахунок ОВФ,\% }\end{array}$ & $\begin{array}{c}\text { Частка екстенсивного } \\
\text { приросту доходів за } \\
\text { рахунок чисельності,\% }\end{array}$ & $\begin{array}{c}\text { Частка } \\
\text { інтенсивного } \\
\text { приросту доходу, \% }\end{array}$ & Перевірка \\
\hline $\mathbf{t}$ & $\mathbf{x T ( t ) т е о р . ~}$ & $\mathbf{x ( e K )}$ & $\mathbf{x}(\mathbf{e L})$ & 5 & $6=3+4+5$ \\
\hline 1 & 2 & 3 & 4 & - & - \\
\hline 1991 & - & - & 0,09 & 19,74 & 100,00 \\
\hline 1992 & 0,066 & 80,16 & 14,23 & 19,74 & 100,00 \\
\hline 1993 & 0,063 & 66,03 & 28,00 & 19,74 & 100,00 \\
\hline 1994 & 0,083 & 52,26 & 26,53 & 19,74 & 100,00 \\
\hline 1995 & 0,054 & 53,72 & $-4,27$ & 19,74 & 100,00 \\
\hline 1996 & 0,046 & 84,53 & $-9,41$ & 19,74 & 100,00 \\
\hline 1997 & 0,037 & 89,67 & 0,76 & 19,74 & 100,00 \\
\hline 1998 & 0,071 & 79,50 & 6,86 & 19,74 & 100,00 \\
\hline 1999 & 0,084 & 73,40 & $-5,50$ & 19,74 & 100,00 \\
\hline 2000 & 0,034 & 85,76 & & & \\
\hline
\end{tabular}

Джерело: розраховано авторами.

Таблиця 5. Розрахунок норми капітальних вкладень

\begin{tabular}{|c|c|c|c|}
\hline Роки t & $\begin{array}{c}\text { Норма капітальних } \\
\text { вкладень Афакт(t) }\end{array}$ & $\begin{array}{c}\text { Норма капітальних вкладень } \\
\text { рівноважного розвитку Ar(t) }\end{array}$ & $\begin{array}{c}\text { Ефективність капітальних } \\
\text { вкладень е(t) }\end{array}$ \\
\hline 1991 & - & - & - \\
\hline 1992 & 0,182675 & 0,092462 & 0,305914 \\
\hline 1993 & 0,143864 & 0,1027 & 0,444449 \\
\hline 1994 & 0,147835 & 0,121758 & 0,70098 \\
\hline 1995 & 0,093778 & 0,053855 & 0,988276 \\
\hline 1996 & 0,131725 & 0,052057 & 0,294276 \\
\hline 1997 & 0,114789 & 0,019828 & 0,417155 \\
\hline 1998 & 0,205751 & 0,148951 & 0,208287 \\
\hline 1999 & 0,241635 & 0,21197 & 0,226103 \\
\hline 2000 & 0,112581 & 0,01939 & 0,530734 \\
\hline середня & 0,146 & 0,070 & 0,404 \\
\hline
\end{tabular}

Джерело: розраховано авторами. 


\section{ЕКОНОМІКА ТА МЕНЕДЖМЕНТ № 4- 2021}

\section{REFERENCES}

[1] Vitlins'kyy, V.V. (2003). Modelyuvannya ekonomiky[Modeling the economy]: Navch. Posibnyk. / Vitlins'kyy V.V.-K.: KNEU,408p. Retrieved from: https://kneu.edu.ua/ua/science_kneu/scientific_schools/mtrve/mtrve_praci/mtrve_prazi/ modeconnpos/ [in Ukrainian].

[2] H.S. Makhurenko, Yu.Yu. Kruk (2018) Prohnoz sprosa na styvydornye usluhy v Ukrayne[ Forecast of demand for stevedoring services in Ukraine]. Rozvytok metodiv upravlinnya ta hospodaryuvannya na transporti- Development of methods of management and administration of transport, no 2 (63), pp. 53-73 [in Ukrainian].

[3] Ivin, Ye.A., Goryacheva, A.S., Kurbatskiy, A.N. (2020). Analiz sostoyaniya i perspektivy razvitiya gruzopotokov cherez morskiye porty Rossii [Analysis of the state and prospects for the development of cargo flows through the seaports of Russia]. Problemy razvitiya territorii- Territory development problems, no 2 (106), pp. 62-80. DOI: 10.15838/ ptd.2020.2.106.5Retrieved from: http://pdt.vscc.ac.ru/article/28510 [in Russian].

[4] Ablyazov, V. K. (2015). Prognozirovaniye gruzooborota morskogo porta v usloviyakh neopredelennosti i riska[Forecasting seaport cargo turnover in conditions of uncertainty and risk]. - Extended abstract of candidate's thesis, NizhniyNovgorod.22p. Retrieved from: https:/www.dissercat.com/content/ prognozirovanie-gruzooborota-morskogo-porta-v-usloviyakhneopredelennosti-i-riska [in Russian].

[5] Semenov, K.M. (2014). Planirovaniye obrabotki gruzov v morskikh portakh i terminalakh na osnove diskretno-sobytiynogo imitatsionnogo modelirovaniya [Scheduling of cargo handling in seaports and terminals based on discrete-event simulation]. Extended abstract of candidate's thesis. Kaliningrad 21p. Retrieved from: http://simulation.su/uploads/files/default/2014abstract-cand-semenov.pdf [in Russian].

[6] Rakhmangulo, A. N., Murav'yev, D. S. (2016). Razvitiye morskoy portovoy infrastruktury regiona na osnove "sukhikh" portov [Development of the region's sea port infrastructure based on dry ports] Ekonomika regiona- Economy of the region, V. 12, vyp. 3, pp. 924-936. Retrieved from: http://simulation.su /uploads/files/default/2016-rahmangulov-muraviev.pdf [in Russian]

[7] Stepanov, O.N. (2005). Teoreticheskiye osnovy razrabotki strategii ekonomicheskogo razvitiya morskogo porta [Theoretical foundations for developing a strategy for the economic development of a seaport]. Doctor's thesis. Odessa. 545 p. [in Ukrainian].

[8] Mel'nykov, S.V. (2005). Optymyzatsyya ob"emov resursov porta pry stepennoy proyzvodstvennoy funktsyy s N resursamy [Optimization of port resource volumes when power production function with $\mathrm{N}$ resources]. Rozvytok metodiv upravlinnya ta hospodaryuvannya na transporti-Development of methods of management and administration of transport. Odesa : ONMU, Vyp. 23, pp. 58-73 [in Ukrainian].

[9] Mel'nykov, S.V. (2005). Optymyzatsyya taryfa y ob"emov resursov porta [Optimization of tariff and volume of port resources]. Metody ta zasoby upravlinnya rozvytkom transportnykh system - Methods for managing the development of transport systems. Odesa : ONMU, Vyp. 9, pp. 71-82 [in Ukrainian].

[10] Makhurenko, G.S., Girina, O.B. (2009). Komp'yuternoye modelirovaniye ekonomicheskikh protsessov[Computer modeling of economic processes] Teksty lektsiy. Odessa : ONMU. 100 p. [in Ukrainian].

\section{СПИСОК ВИКОРИСТАНОЇ ЛІТЕРАТУРИ}

[1] Вітлінський В.В. Моделювання економіки : навчальний посібник. Київ : KHEУ, 2003. 408 с. URL: https://kneu.edu.ua/ua/science kneu/scientific_schools/mtrve/mtrve_praci/mtrve_prazi/modeconnpos/

[2] Махуренко Г.С., Крук Ю.Ю. Прогноз спроса на стивидорные услуги в Украине. Розвиток методів управління та господарювання на транспорті. № 2 (63). 2018. С. 53-73

[3] Ивин Е.А., Горячева А.С., Курбацкий А.Н. Анализ состояния и перспективы развития грузопотоков через морские порты России. Проблемы развития территории. № 2 (106). 2020. С. 62-80. DOI: 10.15838/ ptd.2020.2.106.5 URL: http://pdt.vscc.ac.ru/article/28510

[4] Аблязов В.К. Прогнозирование грузооборота морского порта в условиях неопределенности и риска : автореф. дис. ... канд. эконом. наук. Нижний Новгород, 2015. 22 c. URL: https://www.dissercat.com/content/prognozirovanie -gruzooborotamorskogo-porta-v-usloviyakh-neopredelennosti-i-riska

[5] Семенов К.М. Планирование обработки грузов в морских портах и терминалах на основе дискретно-событийного имитационного моделирования: автореферат дис. ... канд. техн. наук. Калининград, 2014. 21 с. URL: http://simulation.su/uploads/files/default/2014-abstract-cand-semenov.pdf

[6] Рахмангулов А.Н., Муравьев Д.С. Развитие морской портовой инфраструктуры региона на основе «сухих портов» Экономика региона. 2016. Т. 12, Вып. 3. C. 924-936. URL: http://simulation.su/uploads/files/default/2016-rahmangulovmuraviev.pdf

[7] Степанов О.Н. Теоретические основы разработки стратегии экономического развития морского порта : дис. ... докт. экон. наук. Одесса, 2005. 545 с.

[8] Мельников С.В. Оптимизация объемов ресурсов порта при степенной производственной функции с N ресурсами. Розвиток методів управління та господарювання на транспорті. Одеса : ОНМУ, 2005. Вип. 23. С. 58-73.

[9] Мельников С.В. Оптимизация тарифа и объемов ресурсов порта. Методи та засоби управління розвитком транспортних систем: Одеса : ОНМУ. 2005. Вип. 9. С. 71-82.

[10] Махуренко Г.С., Гирина О.Б. Компьютерное моделирование экономических процессов. Тексты лекций. Одесса: OНМУ. 2009100 c.

(C) Гіріна О. Б., Литвиненко А. С. Дата надходження статті до редакції: 19.11.2021 Дата затвердження статті до друку: 03.12.2021 